\title{
AKAD CONSTRUCTION ON CREDIT CARD PRODUCTS (ANALYSIS OF SHARIA ECONOMIC LAWS)
}

\author{
Rahmatul Huda \\ Universitas Islam Kalimantan Muhammad Arsyad Al-Banjary (UNISKA) Banjarmasin \\ Jl. Adhyaksa, Jl. Kayu Tangi 1 Jalur 2 No.2, Sungai Miai, Kec. Banjarmasin Utara, Kota \\ Banjarmasin, Kalimantan Selatan 70123 \\ Email: hoeda.errahmah@gmail.com
}

\begin{abstract}
Abstrak: Islam adalah agama yang universal dan komprehensif, mencakup seluruh aspek kehidupan manusia, aspek ibadah maupun mu'amalah. Kegiatan ekonomi tidak bisa dipisahkan dari kehidupan manusia, karena terkait dengan kebutuhan dan keinginan manusia dalam pemenuhan hajat hidup. Kegiatan ekonomi dan transaksi bisnis termasuk dalam lingkup kajian mu'amalah. Salah satu bentuk pembiayaan yang sangat diminati oleh masyarakat saat ini, salah satunya adalah kartu kredit (credit card). Lembaga perbankan pun berlomba-lomba menerbitkan kartu kredit sebagai bentuk service kepada nasabah. Kartu kredit sekarang mulai menjadi gaya hidup masyarakat sebagai bentuk kemudahan dalam bertransaksi. Berdasarkan latar belakang tersebut, terdapat peluang penelitian yang menarik bagi penulis yaitu tentang model akad pada produk pembiayaan, khususnya kartu kerdit. Untuk itu perlu dibahas dan dikritisi, bagaimana akad dalam produk pembiayaan kartu kredit tersebut yang seharusnya bebas dari akad ribawi. Adapun tujuan penelitian ini adalah untuk mengetahui bagaimana konstruksi akad ribawi pada produk kartu kredit dan menganalisis hukum ekonomi syariah tentang akad pada produk kartu kredit. Jenis penelitian ini merupakan penelitian hukum normatif (normative legal research) dengan pendekatan konseptual (conceptual approach). Berdasarkan metode yang digunakan dihasilkan kesimpulan bahwa akad dalam kartu kredit adalah akad pinjaman (qardh). Tambahan syarat atas pinjaman dari pihak issuer bank hukumnya haram, bila ditinjau dari hukum syariat Islam. Hal ini karena bunga tambahan atas penangguhan pembayaran pinjaman termasuk riba nasiah (riba jabiliyah). Riba ini diharamkan karena adanya tambahan jumlah pinjaman disebabkan penangguhan pembayaran. Penerapan prinsip syari'ah dalam kartu kredit bisa dilaksanakan berdasarkan akad-akad: (a) Kafalah, (b) Qardh, (c) Ijarah.
\end{abstract}

Kata Kunci: Akad, Hukum Ekonomi Syariah, Kartu Kredit

\begin{abstract}
Islam is a universal and comprehensive religion. it covers all aspects of human life, worship and mu'amalah. Economic activities cannot be separated by human life, because they are related to human needs and desires in fulfilling life. Economic activities and business transactions are included in mu'amalah. One of financing that has great demand by the society is a credit card. Banking institutions compete to launch credit card as one of service to customers. In this era, Credit card becomes lifestyle of our society. It helps for doing transaction. Based on this background, there is an opportunity to do a research about the contract model on financing products, especially credit card. For this reason, it needs to be discussed and criticized, how the contract in the credit card financing
\end{abstract}


product should be free from the usury contract. The purpose of this research is to find out how the construction of usury on credit card product and analyze sharia economic law regarding contract on credit card product. This type of research is normative legal research with a conceptual approach. Based on the method, it is found a conclusion that the credit card contract is a loan agreement (qardh. Additional requirements for loans from the issuer bank are illegal, if it is viewed from Islamic law. This is because of the additional interest on the suspension of loan payments including usury nasiah (usury jabiliyab). This usury is prohibited because there is an additional loan that it caused by deferred payment. The application of sharia principles on credit card can be carried out based on contracts: (a) Kafalah, (b) Qardh, (c) Ijarah.

Keywords: Akad, Sharia Economic Law, Credit Card

\section{Introduction}

Islamic economic began in the 90s in Indonesia. This was marked by the establishment of a sharia-based bank pioneered by Islamic Muamalat Bank. In this era, Islamic economic develops rapidly, it is marked by the establishment of banking institution and other non-bank Islamic financial institutions. The role of Islamic banking is very important, so that Islamic banks increase in Indonesia.

The current development of Islamic banking continues, both physical and nonphysical developments. One of them is the development of products in Islamic banking that continue to innovate to answer the all of society needs. This is certainly challenge for the existence of Islamic banking as a solution for Muslims, especially in their efforts.
Islam is a universal and comprehensive religion, covering all aspects of human life. Shari'a which regulates the relationship between man and his God, is called worship. And also the Shari'a that regulates human relations is called mu'amalah. Allah gives Complex and complete rules as guidance for getting better life in this world as well as possible. Economic activities cannot be separated from human life, because they are related to human needs and desires in fulfilling life. Economic activities and business transactions are included in the scope of mu'amalah object.

One form of financing that is in great demand by society is a credit card. Credit card is a type of payment for replacing of cash which can be exchanged at any time for whatever we want and 
branches that can accept credit cards from banks or companies that issue them. Banking institutions are competing to issue credit cards as a form of service to customers. Credit cards are now starting to become people's lifestyles as a form of convenience in transactions. This is data that is obtained from the Indonesian Credit Card Association about the usability of credit cards in Indonesia in recent years: ${ }^{1}$

Picture 1.1. Number of Credit Card Users

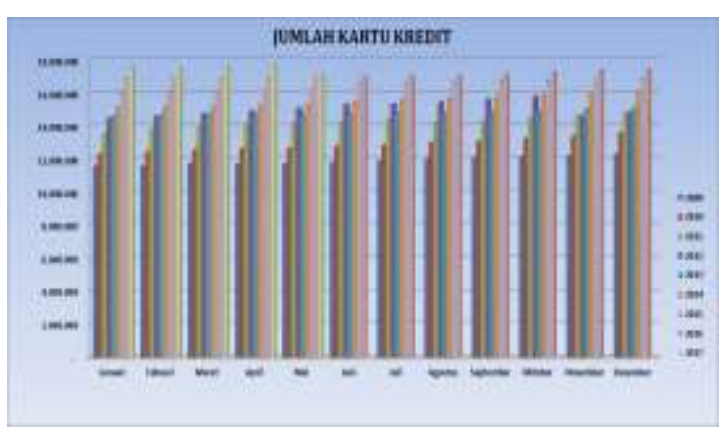

Table 1.1. Credit Card Transaction Growth

\begin{tabular}{|c|c|c|c|}
\hline Year & $\begin{array}{c}\text { Number of } \\
\text { Cards }\end{array}$ & $\begin{array}{c}\text { Number of } \\
\text { Transactions }\end{array}$ & $\begin{array}{c}\text { Transaction } \\
\text { Value }\end{array}$ \\
\hline 2009 & 12.259 .295 & 177.817 .542 & 132.651 .567 \\
\hline 2010 & 13.574 .673 & 194.675 .233 & 158.687 .057 \\
\hline 2011 & 14.785 .382 & 205.744 .761 & 178.160 .763 \\
\hline 2012 & 14.817 .168 & 217.956 .183 & 197.558 .986 \\
\hline 2013 & 15.091 .684 & 235.695 .969 & 219.026 .985 \\
\hline 2014 & 16.043 .347 & 250.543 .218 & 250.177 .517 \\
\hline 2015 & 16.863 .842 & 274.719 .267 & 273.141 .964 \\
\hline 2016 & 17.406 .327 & 297.661 .974 & 272.950 .051 \\
\hline
\end{tabular}

\footnotetext{
${ }^{1}$ Asosiasi Kartu Kredit Indonesia, 17 Juli 2017, Credit Card Growth, http://www.akki.or.id/index.php/credit-card-growth. Diakses pada 20 Juli 2017.
}

https://dx.doi.org/10.18592/sjhp.v19i1.2041

\begin{tabular}{|l|l|l|l|}
\hline $\begin{array}{l}\text { May } \\
2017\end{array}$ & 17.211 .390 & 132.407 .406 & 117.507 .916 \\
\hline
\end{tabular}

Based on data (tabel 1.1), it can be seen that from 2009 to May 2017, the number of credit card users in Indonesia continues to grow. The increase of credit card users is directly proportional to the increase in the number of transactions and transaction value.

Financing products are offered by banks and sharia financing institutions or companies must always hold Islamic principles, which refer to the Qur'an and alhadith. These principles include not containing usury, gharar, and maisir so that the development of economic activities must remain within the corridor of the sharia principle. The Qur'anic propositions that show the prohibition of usury or usury, namely in the letter An-Nisaa, Allah Azza wa Jalla said:

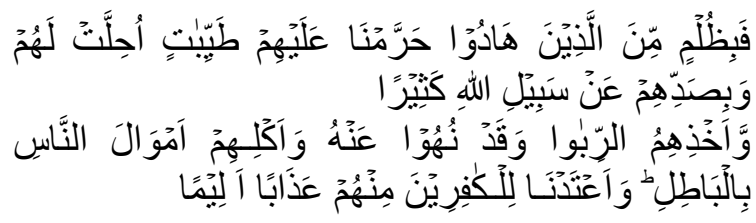
"Because of the wrongdoing of the Jews We forbade them good things which were (before) made lawful unto them, and because of their much bindering from Allah's way, and of their taking usury when they were forbidden it, and of their devouring people's wealth by false pretences, We have prepared for those of them who disbelieve a painful doom." (QS. An-Nisaa' [4]: 160-161)

Based on this background, there are interesting research opportunities for 
writer, namely about the contract model on financing products, especially credit card. For this reason, it needs to be discussed and criticized, how the contract in the credit card financing product should be free from the usury contract. This research will be outlined in a scientific paper entitled "Construction of Contract in Credit Card Product (Analysis of Islamic Economic Law)".

\section{Research Method \\ Type of Research}

Normative research is also often referred to as doctrinal research, which object of study is a legal regulation document and library material. ${ }^{2}$ So, it can be said that this research is normative legal research, because this research studies the rules of law and legislation relating to usury contract, especially on credit card products.

The research is library research, which look for data in a number of literature relates to object that will be studied. This is done by exploring intensively the data relating to usury contract and credit card products and formal legal provisions relating to these problems.

${ }^{2}$ Soejono dan Abdurrahman, Metode Penelitian Hukum, (Jakarta: Rineka Cipta, 2003), h. 56.

\section{Research Approach}

The approach is interpreted as an effort for a research activities to establish relationship with the people or methods to achieve understanding of research problem. ${ }^{3}$ Writer uses a conceptual approach, which is an approach that refers to the views and doctrines that develop in law. ${ }^{4}$ By using the conceptual approach, a study of Islamic legal norms and views of Jurisprudence experts related to usury contract in credit card products will be carried out.

\section{Legal Material}

To solve legal issues and at the same time provide prescription about what should be, research sources needs legal material, ${ }^{5}$ because in legal research is not known data. What is examined in legal research activities is legal materials so that it is appropriate to call library research with a focus on reading and analysis of primary and secondary materials. ${ }^{6}$ The legal materials are used as sources in this research consist of:

${ }^{3}$ Salim HS dan Erlies Septiana Nurbani, Penerapan Teori Hukum pada Penelitian Tesis dan Disertasi, (Jakarta: Rajawali Pers, 2014), h. 17.

4Peter Mahmud Marzuki, Penelitian Hukum, (Jakarta: Kencana, 2005), h. 135.

${ }^{5}$ Ibid., h.181.

${ }^{6}$ Abu Yasid, Aspek-Aspek Penelitian Hukum; Hukum Islam - Hukum Barat, (Yogyakarta: Pustaka Pelajar, 2010), h. 16. 
1. Primary legal material, data that will be used as the main reference in this study comes from the Qur'an and Hadith.

2. Secondary legal material, legal material that provides an explanation of primary legal material, such as laws relating to research, books relating to issues, journals, legal writings and others related to the issues discussed

a. Kitab Undang-Undang Hukum Perdata

b. Kompilasi Hukum Ekonomi Syariah

c. Fatwa-Fatwa dari MUI atau Fatwa menurut Fuqaha.

d. Wahbah Al-Zuhaily, Al-Fiqh AlIslamî Wa Adillatubu, Damsyiq: Dâr al-Fikr, 2006.

e. Sayyid Sâbiq, Fiqh al-Sunnah, Dâr al-Tsaqâfah al-Islamiyyah, tth.

f. Ismail Nawawi, Fikib Muamalah Klasik dan Kontemporer, Bogor: Ghalia Indonesia, 2012.

g. Rachmat Syafe'i, Fiqih Muamalah, Bandung: Pustaka Setia, 2006.

h. Enang Hidayat, Fiqib Jual Beli, Bandung: PT Remaja Rosdakarya, 2015.

i. Salim HS dan Erlies Septiana Nurbani, Penerapan Teori Hukum pada Penelitian Tesis dan Disertasi, Jakarta: Rajawali Pers, 2014.

j. Peter Mahmud Marzuki, Penelitian Hukum, Jakarta: Kencana, 2005.

3. Tertiary legal material, legal material that provides instructions and explains about secondary legal material

a. Tim Penyusun Kamus Pusat Bahasa, Kamus Besar Bahasa Indonesia, ed. 3, cet. 2, Jakarta: Balai Pustaka, 2002.

b. Ahmad Warson Munawwir, Kamus Munawwir Arab-Indonesia, Yogyakarta: Pustaka Progresif, 1984.

c. Kamus Hukum

d. Ensiklopedi

\section{Legal Material Collection Techniques}

To collect legal materials, the techniques are used:

1. Literature survey, writer looks directly at the availability of materials needed in the library that has relation with objects.

2. Inventory, writer collects legal materials such as legislation and literature relates to this research.

3. Study of literature, writer studies, analyzies intensively legal material 
that has been collected by taking sub-sections from the book that discuss the problem becomes the object of research.

\section{Discussion}

\section{Credit Card Definition and Term}

In The Concise Oxford

Dictionary, credit card is small plastic card issued by a bank or building society, allowing the holder to make purchases on credit. The term credit card is used by Arab economist is bithaqah al-i'timan, whereas in its essence it is more appropriate to use the term bithaqah al-iqradh. The right term credit card in Arabic is bithaqah al-iqrad, because the term shows the suitability of the credit card and also shows the real description of the term financial transactions card. ${ }^{7}$ While the word $i^{\prime}$ timan is not the right term and also does not match the characteristics of the credit card, because basically the term has no basic in the validity of the character of the contract. The origin of the word i'timan comes from the word amanah and the word formation is istiman. It means that qiradh in Islamic jurisprudence is not included in the isti'man contract, so it is better to give the term to this credit card

${ }^{7}$ Abdul Wahab Ibrahim Abu Sulaiman, Banking Cards Syariah: Kartu Kredit dan Debit dalam Perspektif Fiqih, (Jakarta: PT RajaGrafindo Persada, 2006), h.20. according to the characteristic that match and describe how is it, as well as the characteristic that suitable with the sharia term.

\section{Parties to the Credit Card Agreement}

In Pasal 1 huruf h PMK No. B4/PMK.12/2006 about Financing Company, Credit Card Business (credit card) is defined as financing activities for the purchase of goods and / or services using a credit card. The parties involved in the relationship with credit card are (1) the issuer, (2) the credit card holder, (3) the seller of goods and services, and (4) the intermediary.

The explanation of the parties involved in dealing with credit card:

1. Issuer Bank (Muqridh)

Institution that has the power to issue cards to customers based on the mandate of the law. The publisher must pay the value of the purchase made to the merchant, as a representative of the card holder. The credit card issuers include banks, specialized financial institutions, and financial institutions besides moving in the issuance of credit cards, and in the activities of other financial institutions. The obligation carried out by the issuer is to give the credit card to the owner, 
make payment of the price of goods or services for bills are offered by the seller, notify the credit card owner of each bill within a certain period, and notify other credit card owners of the news which concern the rights, obligations, and convenience of the owner. In addition to the obligations that must be carried out, the issuer also has the right of receiving back the purchase price of goods or services from the credit card owner, and also the issuer has the right to receive from the billing broker or to the seller in the form of bill payment commission.

\section{Card Holder (Muqtaridh)}

The person whose name is written on the card has the power to use the card, and must pay off all obligations to the issuer bank as an impact of using the card. Legally the credit card holder has an obligation not to make purchases with credit card that exceed the maximum limit, sign the purchase slip offered by the seller of goods / services, make a repayment of the purchase price according to the bill by the credit card issuer, and make payments to other payments, such as base money, annual money, fines, and so on.
The credit card holder has rights such as the right to buy goods / services using a credit card with or without a maximum limit, giving the holder the right to take cash, both on certain teller machines using certain code numbers or via the other banks or issuing bank, and then the right to get some information from the publisher about the development of his credit and about the facilities if there is one intended for the credit card holder.

\section{Merchant}

People that have relation to issuer bank as a result of delivering goods and services to the card holder. The seller of goods or services, legally have obligations such as allow the credit card holder to buy goods / services using a credit card, check or authorize the use and validity of the credit card, inform the holder / buyer of the goods / services about an additional charge of a percentage of the sales price of a purchase by using a credit card for certain types of products, offering a purchase slip to be signed by the buyer / credit card holder, paying commissions when billing to intermediaries (if used by intermediaries) or to the issuer done directly to the publisher). 
Whereas the seller of goods or services has the right to ask the buyer / credit card holder to sign the purchase slip, refuse to sell goods / services if there is authorization from the credit card issuer, and ask for the payment of the goods / services purchased by the buyer using a credit card.

\section{Intermediaries}

The intermediary is divided into two, namely (1) billing intermediary (between seller and publisher), and (2) intermediary payment (between holders and publishers).

The acquirer is a part who receives a bill from the seller of goods / services to forward the bill to the publisher. the billing intermediary makes payments to the seller. The amount to be paid to the seller will be subject to commission deductions by the intermediary, if the billing intermediary is separate from the issuer, then as well as the billing intermediary bill to the publisher.

The payment intermediaries are banks where credit payments / prices are carried out by credit card owners. Furthermore, these banks will send the payment to the issuer, so the intermediary bank will get fee. This payment intermediary has the same rights and obligations as the provision of other money transfer services as usual.

In credit card products is not only used one contract, but it contains several different agreements. The contracts must fulfill all the requirements and each contract must be seen as a contract that is different from the other contract. Credit agreements are considered absolute and not bound if the agreement contains a cash credit agreement and is not bound by the purchase of certain goods.

The contract that is used of credit cards is separated, it appears in terms of: first, the sale and purchase agreement between the merchant and the card holder; secondly, contracts between merchants and issuer cards that will cover the repayment of a number of bills purchased by the card holder from the merchant are reflected in documents signed by the card holder; third, the agreement between card issuers and card holders. ${ }^{8}$

It means that three separate contracts with three separate parties also exist, each individual is one part in two contracts of the three existing contracts. However, one of them will not become a part in the third contract.

8Ibid., h.73. 
Contract Construction in a Credit Card

Credit card contract is loan agreements. Etymologically, the sentence al-qardhu is mashdar, which means a gift of someone to someone who is then required to be returned. In terms of fiqih, it means giving property to someone closest to the beneficiary of the property which then returns can be in the form of the same property or other equivalent objects. ${ }^{9}$

So, ta'rif qardh in syar'i is general and includes everything called property in the definition of a credit card.

Al-iqtiradh: receipt of assets in the framework of qardh

Al-muqridh: who gives wealth

Al-muqtaridh: recipient of assets / borrowers

Badlu al-qardh: assets handed over by the borrower to the lender in exchange for debt

Al-dain: a liability due to the existence of a contract, or the contract of dependence is a debt due to borrowing.

Islamic Sharia encourages people to be able to set aside part of their wealth to be given to people who need to help their difficulties. There are several hadith that explain that people who give loans to others will get a large reward and a high degree. The history of Abdullah bin Mas'ud in the hadith of marfu ', Rasulullah saw. said: "Muslims who give loans twice as if they giving once." (Ibn Majjah).

Maqashid al-syar'i in the iqradh contract does not allow to use loan contracts as investment tools or use contracts to develop assets. Additional conditions for loans from the issuer are illegal, if viewed from Islamic law. This is because of the additional interest on the suspension of loan payments including usury nasiah (usury jahiliyah). Usury is prohibited because there is an additional loan amount due to deferred payments. As in verse Al-Qur'an:

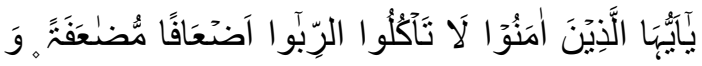

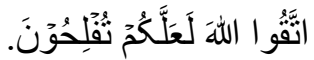

"O ye who believe! Devour not usury, doubling and quadrupling (the sum lent). Observe your duty to Allah, that ye may be successful." (Al-Imran [3]:130).

Usury is prohibited, although it does not multiply this according to most scholars of islam. There are two types of usury, namely nasiah and fadhl. nasiah is more payment required by the person who lends. fadhl is the exchange of goods with similar goods, but more in number because the person exchanging requires such things, such as exchanging gold with gold, rice with rice, and so on. Whereas in the verse above, the meaning is nasiab which has

9'Ibid., h.109-110. 
multiplied that is common in the Arab society of the jahiliyah era.

The reason for the prohibition of additional loans is also based on the hadith of Imam Ali r.a., Rasulullah saw. said which means: "Every loan that attracts benefits, then the law is usury". Mutawatir hadiths that explain the meaning of usury affirm the prohibition of lenders to take advantage of their loans in any form. This law cannot be denied in Islamic jurisprudence. If the requirements provide benefits to the lender, it means leaving the loan agreement. The loan should be a pleasant contract and intends to approach God.

\section{Legal Analysis of Sharia Economics on}

\section{Credit Card}

Business Credit Card (credit card) is financing activities for the purchase of goods and/or services using a credit card. The parties involved in the credit card relationship are: a) The Issuer consists of Bank or Financial Institution, b) the Card Holder, c) the Goods / Services Seller, and d) the Intermediary Party consists of billing intermediaries (between seller and publisher) and payment intermediaries (between holders and publishers). ${ }^{10}$ The

\footnotetext{
${ }^{10}$ Abdul Ghofur Anshori, Penerapan Prinsip Syariab dalam Lembaga Keuangan, Lembaga Pembiayaan, dan Perusabaan Pembiayaan, (Yogyakarta: Pustaka Pelajar, 2008), h.180-181.
}

application of shari'ah principles on credit cards can be seen in the DSN Fatwa NO. 54/DSN-MUI/X/2006 About Sharia Cards.

The contracts used are: ${ }^{11}$

\section{Kafalah}

In this case the card issuer is the guarantor (kafil) for the card holder towards the merchant for all payment obligations (dayn) arising from transactions between the card holder and the merchant. For giving kafalah, the card issuer can receive a fee (ujrah kafalab).

\section{Qardh}

In this case the card issuer is the lender (muqridh) to the card holder (muqtaridh) through cash withdrawals from the bank or bank card issuer's ATM.

\section{Ijarah}

In this case the card issuer is a provider of payment system services and services to card holder. For this ijarah, the card holder is charged a membership fee.

In the fifth part the DSN Fatwa NO. 54 / DSN-MUI / X / 2006 about Sharia Card, regulating fees which are contravention received by the issuer for services provided to its customers. When the card application contract, all forms of

\footnotetext{
${ }^{11}$ Majelis Ulama Indonesia, Himpunan Fatwa Kenangan Syariab; Dewan Syariab Nasional MUI, Jakarta: Erlangga, 2014), h. 302-320.
} 
fees must be clearly defined and fixed, except for merchant fees. The fee forms mentioned in this fatwa are:

\section{Fifth: Fee provisions}

a. Membership fee

Card Issuer is entitled to receive membership fees (Rusum al-'udhwiyah) including the extension of the membership period from Card holder as a reward (ujrah) with permission use of card facilities.

b. Merchant fee

Card Issuer may receive fees that is taken from prices object of transaction or service as wages / benefits (ujrah) for intermediaries (samsarah), marketing (taswiq) and billing (tabsil al-dayn).

c. Fee for cash withdrawals

Card issuer may accept cash withdrawal fees (rusum sabb al-nuqud) as a fee for services and use of facilities that size is not associated with number of withdrawals.

d. Fee Kafalab

Card issuer may receive fees from the Card Holder for giving Kafalah.

e. All fees mentioned above (a s-d d) must be determined when the card application contract is clear and permanent, except for merchant fees.
For card issuer, things that need to be considered are cash withdrawal fees as fees for services and use of facilities which amount is not associated with the number of withdrawals. In order not to be included in the practice of usury, the fee may not be associated with the number of withdrawals, because the fee is feared based on the amount of the loan received by the customer.

Then related $t a^{\prime}$ widh and charge are mentioned in the sixth part of the DSN Fatwa NO. 54 / DSN-MUI / X / 2006 About Sharia Cards, namely:

\section{Sixth: Ta'widh and charge}

a. Ta'widh

The Card Issuer may impose ta'widh, namely compensation the costs incurred by the Card Issuer due to late card holders paying obligations that have matured.

b. Late charge

Card issuers may charge late fees payments that will be recognized entirely as social funds.

The limitations that must be considered in the issuance of credit cards in the form of shari'ah cards are not to cause usury, not used for transactions that are not in accordance with sharia, do not encourage excessive expenditure (israf), by setting the maximum expenditure, the main 
card holder must have the financial capacity to pay off in time, and not provide facilities that are contrary to the Shari'ah.

\section{Conclusion}

Based on the results of research conducted by researchers, these are the conclution:

1. In conventional financing, generally use the principle of usury in the application of its products. The contract in the credit card is a loan contract (qardh). Maqashid al-syar'i in the qardh contract does not allow to use loan contracts as investment tools or use contracts to develop assets. Additional conditions for loans from the issuer are illegal, ifit is viewed from Islamic law. This is because of the additional interest on the suspension of loan payments including usury nasiah (riba jabiliyah). Usury is prohibited because there is an additional loan amount due to deferred payments.

2. The application of shari'ah principles on credit cards can be carried out based on contracts: (a) Kafalah, in this case the card issuer is the guarantor (kafil) for the card holder towards the merchant for all payment obligations (dayn) arising from transactions between holders card with the merchant. For giving kafalah, the card issuer can receive a fee (ujrah kafalah). (b) Qardh, in this case the card issuer is the lender (muqridh) to the card holder (muqtaridh) through cash withdrawal from the bank or ATM of the Card Issuer bank. (c) Ijarah, in this case the card issuer is a provider of payment system services and services to card holders. For this ijarah, the card holder is charged a membership fee.

\section{References}

Abu Sulaiman, Abdul Wahab Ibrahim. 2006. Banking Cards Syariab: Kartu Kredit dan Debit dalam Perspektif Fiqih, Jakarta: PT RajaGrafindo Persada.

Al-Bugha, Musthafa Dib, 2010, Buku Pintar Transaksi Syariab; Menjalin Kerja Sama Bisnis dan Menyelesaikan Sengketanya Berdasarkan Panduan Islam, Jakarta: Hikmah.

Anshori, Abdul Ghofur, 2008, Penerapan Prinsip Syariah dalam Lembaga Keuangan, Lembaga Pembiayaan, dan Perusahaan Pembiayaan, Yogyakarta: Pustaka Pelajar.

Antonio, Muhammad Syafi'i, 2001, Bank Syariab: Dari Teori Ke Praktik, Jakarta: Gema Insani Press.

Anwar, Syamsul, 2010, Hukum Perjanjian Syariab; Studi tentang 
Teori Akad dalam Fikih Muamalat, Jakarta: Rajawali Pres.

Ascarya, 2008, Akad dan Produk Bank Syariah, Jakarta: PT. RajaGrafindo Persada.

Departemen Agama RI, 2008, AlQur'an dan Terjemahnya, Bandung: Diponegoro.

Diana, Ilfi Nur, 2011, Hadis-Hadis Ekonomi, Malang: UIN-Maliki Press.

Fatoni, Siti Nor, 2014, Pengantar Ilmu Ekonomi, Dilengkapi Dasar-Dasar Ekonomi Islam, Bandung: Pustaka Setia.

Karim, Adiwarman, 2006, Bank Islam; Analisis Fiqib dan Kenangan, Jakarta: PT RajaGrafindo Persada.

Majelis Ulama Indonesia, 2014, Himpunan Fatwa Keuangan Syariab; Dewan Syariab Nasional MUI, Jakarta: Erlangga.

Marzuki, Peter Mahmud, 2005, Penelitian Hukum, Jakarta: Kencana.

Munawir AF, dan Adib Bisri, 1999, Kamus Al-Bisri: Indonesia-Arab Arab-Indonesia, Surabaya: Pustaka Progressif.
Naja, Daeng, 2006, Legal Audit Operational Bank, Yogyakarta: PT. Citra Aditya Bakri.

Salim HS, dan Erlies Septiana Nurbani, 2014, Penerapan Teori Hukum pada Penelitian Tesis dan Disertasi, Jakarta: Rajawali Pers.

Soejono, dan Abdurrahman, 2003, Metode Penelitian Hukum, Jakarta: Rineka Cipta.

Soekanto, Soerjono, dan Sri Mamudji, 2011, Penelitian Hukum Normatif, Jakarta: PT. Raja Grafindo Persada.

Soemitra, Andri, 2009, Bank dan Lembaga Keuangan Syariah, Jakarta: Kencana.

Suhendi, Hendi, 2010, Fiqh Muamalah, Jakarta: Rajawali Press.

Yasid, Abu, 2010, Aspek-Aspek Penelitian Hukum; Hukum Islam Hukum Barat, Yogyakarta: Pustaka Pelajar.

Asosiasi Kartu Kredit Indonesia, 17 Juli 2017, Credit Card Growth, http://www.akki.or.id/index.php /credit-card-growth. Accessed on July 20, 2017. 